International Journal of Current Advanced Research

ISSN: O: 2319-6475, ISSN: P: 2319 - 6505, Impact Factor: SJIF: 5.995

Available Online at www.journalijcar.org

Volume 6; Issue 5; May 2017; Page No. 3867-3871

DOI: http://dx.doi.org/10.24327/ijcar.2017.3871.0384

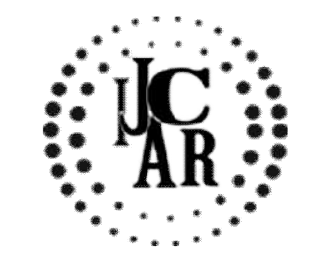

Research Article

\title{
CONSTRUCTION OF KNOWLEDGE TEST TO MEASURE THE PADDY GROWERS KNOWLEDGE ON RECOMMENDED CROP PRODUCTION PACKAGE OF PRACTICES IN TAMIL NADU STATE
}

\section{Sureshverma R ${ }^{1 *}$,, Samuel G²., Sreenivasa Rao I ${ }^{3}$ and Qudsiyajamal $\mathrm{K}^{4}$}

1,2,3 College of Agriculture, Prof. Jayashankar Telangana State Agricultural University, R'Nagar, Hyderabad, Telangana

${ }^{4}$ Department of Agricultural Extension \& Rural Sociology, AC \& RI, Madurai, Tamil Nadu Agricultural University, Tamil Nadu

\section{A R T I C L E I N F O}

\section{Article History:}

Received $25^{\text {th }}$ February, 2017

Received in revised form $2^{\text {nd }}$ March, 2017

Accepted $11^{\text {th }}$ April, 2017

Published online $28^{\text {th }}$ May, 2017

\section{Key words:}

Knowledge test, unreached farmers and recommended practices

\begin{abstract}
A B S T R A C T
The non-availability of a standardized scale to measure unreached farmer's knowledge level influenced the researchers to construct a test for measuring knowledge of unreached farmers of Tamil Nadu state on recommended paddy production package of practices. Pertinent items were collected covering all aspects from crop production guide developed by TNAU. After getting jury opinion on the items, test index of item difficulty, index of item discrimination and index of item validity were worked out. To administer the knowledge test a respondent was given one mark for each correct answer and zero for wrong answer. Thirty five (35) statements were finally selected from a total of sixty (60) statements.
\end{abstract}

Copyright $(2017$ Sureshverma $\boldsymbol{R}$ et al. This is an open access article distributed under the Creative Commons Attribution License, which permits unrestricted use, distribution, and reproduction in any medium, provided the original work is properly cited.

\section{INTRODUCTION}

In the present study knowledge was operationalized as the quantum of information known to the unreached farmers on recommended crop production package of practices in order to lead a sustainable life. A knowledge test was developed with thirty five (35) items to measure the knowledge of unreached farmers on recommended practices. Each item was measured on two point continuum viz., correct and incorrect with ' 1 ' and ' 0 ' score respectively. The possible maximum and minimum scores to be obtained by unreached farmers were 35 and 0 respectively. The detailed procedure followed for the construction and standardization of the knowledge test is shown below.

\section{MATERIALS AND METHODS}

\section{Collection of items}

On perusal of relevant literatures and discussion with the experts in extension, biological sciences, a total of 72 items were collected focusing on various aspects of paddy cultivation i.e., crop improvement, production and protection by referring the crop production guide of Tamil Nadu Agricultural University on Agritech portal. Experts in the field of Agronomy and Agricultural entomology of Prof. Jayashankar Telangana State Agricultural University were consulted for screening, fine tuning and editing of the items.

*Corresponding author: Sureshverma R

College of Agriculture, Prof. Jayashankar Telangana State

Agricultural University, R'Nagar, Hyderabad, Telangana
Based on the opinion of the scientists a total of sixty (60) items were retained. These retained sixty (60) items were then subjected to item analysis to have suitable items to be included in the final schedule based on the opinion of the respondents from non-sample area.

\section{Item analysis}

The item analysis was carried out in terms of three indices that is item difficulty index, item discrimination index and point-biserial correlation. The index of item discrimination provides information on how well an item discriminates well informed respondent from poorly informed. Whereas item difficulty index indicates the extent to which an item was difficult. The main aim of calculating Point biserial correlation (rpbis) was to work out the internal consistency of the items i.e., the relationship of the total score to a dichotomized answer to any given item.

\section{Difficulty index (P)}

The selected items ( 60 items for paddy) were administered to 60 non-sample respondents with two point continuum response for each statement. The scores allotted were one (1) for correct response and zero (0) for incorrect response. After computing the total score obtained for each of the 60 respondents on items, they were arranged in order from highest to lowest. Based on which the 60 respondents were then divided into six equal groups. These groups were labelled as G1, G2, G3, G4, G5 and G6 with 10 respondents in each group. 
Difficulty index $=$

Total number of correct answers

For the purpose of item analysis, the middle two groups G3 and G4 were eliminated keeping only four extreme groups with high and low scores. The index of 'Item difficulty' was worked out as the percentage of the respondents answering an item correctly. The items with 'p' values ranging from 30.0 to
70.0 were considered for the final selection of the knowledge test. For each item the correct answer was calculated to get the difficulty index. The results were presented in table 1.

\section{Discrimination Index (E 1/3)}

Where S1, S2 and S5, S6 are the frequencies of correct answers in the groups G1, G2, G5 and G6 respectively. ' $\mathrm{N}$ ' is the total member of respondents of the sample selected for the item analysis that is 60 .

Table 1 Calculation for selection of suitable knowledge items for paddy crop

\begin{tabular}{|c|c|c|c|c|c|c|c|c|c|}
\hline \multirow[b]{2}{*}{ Sl. No. } & \multicolumn{4}{|c|}{$\begin{array}{c}\text { Frequencies of correct answer of respondents } \\
\text { in four extreme groups } \\
\end{array}$} & & \multirow{2}{*}{$\begin{array}{c}\begin{array}{c}\text { Difficulty } \\
\text { index }\end{array} \\
\text { (P) }\end{array}$} & $\begin{array}{c}\text { Discrimination } \\
\text { power }\end{array}$ & \multirow{2}{*}{$\begin{array}{l}\text { Point Biserial } \\
\text { Correlation } \\
\text { (Rpbis) }\end{array}$} \\
\hline & G-1 & G-2 & G-5 & G-6 & $\begin{array}{l}\text { correct answers by all g } \\
\text { six groups }\end{array}$ & $\begin{array}{l}\text { giving correct } \\
\text { responses }\end{array}$ & & (E 1/3) & \\
\hline $1 *$ & 10 & 7 & 5 & 1 & 39 & 65 & 57.5 & 0.55 & $0.551^{*}$ \\
\hline 2 & 10 & 9 & 3 & 1 & 37 & 61.66 & 57.5 & 0.75 & 0.665 \\
\hline $3 *$ & 10 & 8 & 5 & 0 & 42 & 70 & 57.5 & 0.65 & $0.609^{*}$ \\
\hline $4 *$ & 10 & 5 & 5 & 2 & 38 & 63.33 & 55 & 0.4 & $0.403^{*}$ \\
\hline $5 *$ & 8 & 6 & 2 & 1 & 38 & 63.33 & 42.5 & 0.55 & $0.421^{*}$ \\
\hline $6^{*}$ & 10 & 8 & 6 & 2 & 46 & 76.67 & 65.0 . & 0.5 & $0.472 *$ \\
\hline $7 *$ & 10 & 7 & 2 & 2 & 39 & 65 & 52.5 & 0.65 & $0.557^{*}$ \\
\hline 8 & 8 & 9 & 1 & 1 & 35 & 58.33 & 47.5 & 0.75 & 0.593 \\
\hline 9 & 9 & 9 & 2 & 0 & 32 & 53.33 & 50 & 0.8 & 0.679 \\
\hline $10 *$ & 10 & 8 & 7 & 3 & 52 & 86.67 & 70 & 0.4 & $0.419^{*}$ \\
\hline $11 *$ & 9 & 9 & 4 & 1 & 45 & 75 & 57.5 & 0.65 & $0.530^{*}$ \\
\hline 12 & 9 & 10 & 2 & 2 & 38 & 63.33 & 57.5 & 0.75 & 0.599 \\
\hline 13 & 8 & 6 & 3 & 2 & 43 & 71.67 & 47.5 & 0.45 & 0.346 \\
\hline 14 & 9 & 7 & 4 & 2 & 43 & 71.67 & 55 & 0.5 & 0.379 \\
\hline $15^{*}$ & 9 & 8 & 4 & 2 & 41 & 68.33 & 57.5 & 0.55 & $0.475^{*}$ \\
\hline 16 & 8 & 6 & 4 & 2 & 33 & 55 & 50 & 0.4 & 0.345 \\
\hline $17 *$ & 10 & 7 & 4 & 4 & 50 & 83.33 & 62.5 & 0.45 & $0.445^{*}$ \\
\hline $18^{*}$ & 10 & 10 & 4 & 4 & 50 & 83.33 & 70 & 0.6 & $0.523^{*}$ \\
\hline $19 *$ & 10 & 7 & 3 & 0 & 38 & 63.33 & 50 & 0.7 & $0.629 *$ \\
\hline $20 *$ & 9 & 10 & 4 & 2 & 47 & 78.33 & 62.5 & 0.65 & $0.536^{*}$ \\
\hline $21 *$ & 9 & 6 & 2 & 1 & 32 & 53.33 & 45 & 0.6 & $0.517 *$ \\
\hline 22 & 8 & 8 & 5 & 2 & 48 & 80 & 57.5 & 0.45 & 0.336 \\
\hline 23 & 7 & 9 & 5 & 2 & 43 & 71.67 & 57.5 & 0.45 & 0.337 \\
\hline 24 & 10 & 9 & 2 & 1 & 35 & 58.33 & 55 & 0.8 & 0.657 \\
\hline 25 & 6 & 6 & 4 & 2 & 37 & 61.67 & 45 & 0.3 & 0.268 \\
\hline 26 & 10 & 9 & 3 & 0 & 31 & 51.67 & 55 & 0.8 & 0.689 \\
\hline $27 *$ & 9 & 8 & 2 & 2 & 36 & 60 & 52.5 & 0.65 & $0.501 *$ \\
\hline $28 *$ & 9 & 8 & 5 & 3 & 44 & 73.33 & 62.5 & 0.45 & $0.406^{*}$ \\
\hline 29 & 10 & 9 & 1 & 2 & 41 & 68.33 & 55 & 0.8 & 0.599 \\
\hline $30 *$ & 10 & 7 & 2 & 2 & 43 & 71.67 & 52.5 & 0.65 & $0.496^{*}$ \\
\hline $31 *$ & 9 & 7 & 2 & 1 & 29 & 48.33 & 47.5 & 0.65 & $0.548^{*}$ \\
\hline 32 & 8 & 7 & 5 & 4 & 48 & 80 & 60 & 0.3 & 0.315 \\
\hline $33 *$ & 8 & 10 & 4 & 2 & 37 & 61.67 & 60 & 0.6 & $0.511^{*}$ \\
\hline $34 *$ & 9 & 8 & 2 & 2 & 37 & 61.67 & 52.5 & 0.65 & $0.518^{*}$ \\
\hline 35 & 9 & 8 & 6 & 1 & 44 & 73.33 & 60 & 0.5 & 0.493 \\
\hline 36 & 8 & 8 & 5 & 3 & 42 & 70 & 60 & 0.4 & 0.336 \\
\hline $37 *$ & 10 & 8 & 5 & 1 & 46 & 76.67 & 60 & 0.6 & $0.500^{*}$ \\
\hline 38 & 8 & 8 & 1 & 0 & 33 & 55 & 42.5 & 0.75 & 0.551 \\
\hline $39 *$ & 9 & 7 & 3 & 3 & 41 & 68.33 & 55 & 0.5 & $0.436^{*}$ \\
\hline $40 *$ & 10 & 9 & 5 & 2 & 48 & 80 & 65 & 0.6 & $0.541^{*}$ \\
\hline 41 & 5 & 7 & 2 & 1 & 36 & 60 & 37.5 & 0.45 & 0.312 \\
\hline 42 & 10 & 7 & 1 & 0 & 42 & 70 & 45 & 0.8 & 0.583 \\
\hline $43 *$ & 9 & 10 & 6 & 2 & 55 & 91.67 & 67.5 & 0.55 & $0.498^{*}$ \\
\hline $44^{*}$ & 10 & 7 & 4 & 2 & 50 & 83.33 & 57.5 & 0.55 & $0.462 *$ \\
\hline $45^{*}$ & 9 & 7 & 3 & 1 & 44 & 73.33 & 50 & 0.6 & $0.472 *$ \\
\hline $46^{*}$ & 10 & 9 & 4 & 3 & 54 & 90 & 65 & 0.6 & $0.484 *$ \\
\hline 47 & 10 & 9 & 1 & 3 & 44 & 73.33 & 57.5 & 0.75 & 0.511 \\
\hline 48 & 10 & 8 & 3 & 6 & 56 & 93.33 & 67.5 & 0.45 & 0.394 \\
\hline $49 *$ & 8 & 8 & 2 & 2 & 44 & 73.33 & 50 & 0.6 & $0.418^{*}$ \\
\hline $50 *$ & 9 & 8 & 2 & 1 & 38 & 63.33 & 50 & 0.7 & $0.584^{*}$ \\
\hline 51 & 10 & 9 & 4 & 6 & 56 & 93.33 & 72.5 & 0.45 & 0.357 \\
\hline $52 *$ & 10 & 6 & 3 & 2 & 43 & 71.67 & 52.5 & 0.55 & $0.469^{*}$ \\
\hline $53 *$ & 10 & 10 & 5 & 3 & 53 & 88.33 & 70 & 0.6 & $0.513^{*}$ \\
\hline 54 & 10 & 6 & 3 & 5 & 46 & 76.67 & 60 & 0.4 & 0.328 \\
\hline $55^{*}$ & 9 & 5 & 1 & 1 & 25 & 41.67 & 40 & 0.6 & $0.527^{*}$ \\
\hline 56 & 9 & 8 & 5 & 3 & 52 & 86.67 & 62.5 & 0.45 & 0.367 \\
\hline $57 *$ & 10 & 9 & 5 & 4 & 50 & 83.33 & 70 & 0.5 & $0.424 *$ \\
\hline $58 *$ & 10 & 8 & 4 & 5 & 50 & 83.33 & 67.5 & 0.45 & $0.400 *$ \\
\hline 59 & 8 & 6 & 4 & 2 & 41 & 68.33 & 50 & 0.4 & 0.319 \\
\hline
\end{tabular}


The discrimination index varies from 0 to 1 . The items with discrimination index ranging from 0.30 to 0.70 were selected for the final test.

This shows whether the items actually distinguished a wellinformed person from one who is inadequately informed about the subject matter. The formula used was as below. This is the second criterion for item selection i.e., by the item discrimination index indicated by ' $\mathrm{E} 1 / 3$ ' is calculated with the formula.The results were presented in table 1 .

$(\mathrm{S} 1+\mathrm{S} 2)-(\mathrm{S} 5+\mathrm{S} 6)$

\section{$\mathrm{N} / 3$}

\section{(or)}

$$
\mathrm{D}=\frac{\mathrm{R}_{\mathrm{u}}-\mathrm{R}_{1}}{\mathrm{~N}}
$$

Where,

D : Discrimination Index

$\mathrm{R}_{\mathrm{u}} \quad$ : Frequency of correct answers in high knowledge group

$\mathrm{R}_{1} \quad$ : Frequency of correct answers in low knowledge group

$\mathrm{N} \quad$ : Total number of respondents in sample taken for item analysis

\section{Point Biserial Correlation ( $\left.\boldsymbol{r}_{p b i s}\right)$}

The main aim of calculating point biserial correlation (rpbis) was to work out the internal consistency of the items i.e., the relationship of the total score to a dichotomized answer to any given item. It is the correlation between right/wrong scores obtained by farmers in the non-sample area (Thiruvannamalai district) on a given set of items. The total scores the farmers obtained when their scores across the remaining items were summed up. It is a special type of correlation between a dichotomous variable (the multiple-choice item score which is right or wrong, 0 or 1) and a continuous variable (the total score on the test ranging from 0 to the maximum number of multiple-choice items on the test). Like in all correlations, point-biserial values range from -1.0 to +1.0 . A large positive point-biserial value indicates that farmers with high scores on the overall test are also getting the item right and farmers with low scores on the overall test are getting the item wrong (Seemavarma, 2015). The results were presented in table 1.

\section{Computation and interpretation of Point-Biserial Correlation}

The scores obtained by the farmers are arranged in matrix comprised of 60 items. The items were represented in the matrix columns from left to right and farmers represented as rows. A value of ' 1 ' was assigned to correct response and ' 0 ' for wrong.The steps followed for computing Point-Biserial Correlationare 1. computed the total farmers score for each items 2.computed the total score minus each item score, 3.computed the Point-Biserial Correlation for each item using the 'CORREL' function.

A low point biserial implies that the farmer got the items incorrect. Therefore, items with low-point-biserial correlation values need further examination. It was reported by Seemavarma (2015) that the wordings, presentation or content of such items may explain the low point-biserial correlation. However, even if nothing appears visibly faulty with the items, it is recommended that they may be removed from scoring and future testing or may even be removed from final set of questions that may be included in the interview schedule. It is always recommended to use a minimum threshold value for the point-biserial correlation. A point biserial value of at least 0.15 is recommended (Seemavarma, 2015) though experience shown that a very good number of items have point-biserial correlation value.

\section{Point biserial correlation: item discrimination}

The items to be considered for final inclusion into the interview schedule were based on its point biserial correlation value. Penn (2009) and McGahee and Ball (2009) have categorized items based on items point biserial correlation value i.e., the items which possess the point biserial correlation value of 0.20 and below said to be 'poor' and need revision, $0.20-0.29$ said to be 'fair', $0.30-0.39$ said to be 'good' and $0.40-0.70$ said to be 'very good'. In the present study, the items which belong to 'very good' category (i.e., the items with point biserial correlation value of $0.40-0.70$ ) were selected for final inclusion in the interview schedule.

\section{Item selection}

The items with difficulty level indices ranging from 30.0 to 70.0 , discrimination indices ranging from 0.30 to 0.70 and the items with point biserial correlation ranging from 0.40 to 0.70 level were selected finally to include in the interview schedule for assessing the level of knowledge of unreached farmers on recommended crop production package of practices. A total of 35 knowledge items for paddy were finally selected (table 2).

Thus, the finally selected knowledge test items comprised of 3 types of questions viz true/false, multiple choice and direct one word questions. The selected items with frequency of correct response, P, E1/3 and Rpbis values for the selected.

\section{Reliability of knowledge test}

According to Kerlinger (1973) "Reliability is the accuracy or precision of measuring instrument". To know the reliability of the items the Split-Half method was followed.

\section{Split-Half Methodology}

The reliability of the scale was determined by split-half method. The selected items i.e., thirty five (35) items were divided into two halves. The two halves were further administered separately to 30 unreached farmers in a nonsample area (Thiruvannamalai district). The scores were subjected to product moment correlation test in order to find out the reliability of the scale. The half-test reliability coefficient (r) was 0.431 . Further, the reliability co-efficient of the whole test was computed using the Spearman Brown Prophecy formula (Singh, 1986) given below.

$$
2 \times \text { Reliability co-efficient of half test }
$$

\section{Reliability co-efficient of whole test $=$}

$$
1+\text { Reliability co-efficient of half test }
$$

The whole test reliability co-efficient of the whole test was computed using the Spearman Brown Prophecy worked out and the results were 0.603 for the items selected for paddy crop. According to Singh (1986), when the mean scores of the two groups are of narrow range, reliability co-efficient of 0.50 
or 0.60 would be sufficient. Hence, the constructed scale to assess unreached farmers knowledge was considered reliable. earlier. It was assumed that the score obtained by administering the knowledge test of this study measures what was intended to measure.

Table 2 Knowledge items identified for paddy crop to be included in the interview schedule

\begin{tabular}{|c|c|c|}
\hline Sl. No. & $\begin{array}{c}\text { Selected } \\
\text { questions }\end{array}$ & Knowledge items for paddy (included in the interview schedule) \\
\hline 1 & 1 & How much land is required to raise paddy nursery for one hectare of paddy cultivation? \\
\hline 2 & 3 & $\begin{array}{l}\text { What is the chemical used for seed treatment in paddy } \\
\text { a. Carbendazim b. Pyroquilonc.Both a and b d. none }\end{array}$ \\
\hline 3 & 4 & How many days the paddy crop can be protected, when it is given wet seed treatment \\
\hline 4 & 5 & Do you agree that, length of the seed bed varies with soil type and slope of the land \\
\hline 5 & 6 & Soon after sowing the seed in nursery, what is the probable period of maintaining soil water saturation level \\
\hline 6 & 7 & Is it necessary to increase the water level upto $1.5 \mathrm{~cm}$ from the $6^{\text {th }}$ day onwards ___ (T/F) \\
\hline 7 & 10 & Level of water to be maintained during puddling in the mainfield __ $\mathrm{cm}$ \\
\hline 8 & 11 & How many days before puddling of mainfield the sufficient water has to be maintained \\
\hline 9 & 15 & How much time the seedlings are to be kept in the bacterial suspension before transplanting \\
\hline 10 & 17 & What is the number of seedling to be transplanted per hill \\
\hline 11 & 18 & Do you agree that shallow planting $(3 \mathrm{~cm})$ of paddy in the main field ensures quick establishment and more tillers. $(\mathrm{T} / \mathrm{F})$ \\
\hline 12 & 19 & What is the best amendment for overcoming the salinity problem in the paddy fields \\
\hline 13 & 20 & Do you feel that gap filling is not required during 7-10 days after transplanting _ \\
\hline 14 & 21 & Is it is sufficient to maintain the spacing of $5 \mathrm{~cm}$ in the main field for running the rotary weeder \\
\hline 15 & 27 & $\begin{array}{l}\text { What is the quantity of FYM to be applied in one hectare } \\
\begin{array}{llll}\text { a. } 12.5 \text { t b. } 15.5 \mathrm{t} & \text { c. } 17.5 & \text { d. } 20.5\end{array}\end{array}$ \\
\hline 16 & 28 & $\begin{array}{l}\text { At which day of transplanting you take observations with the help of LCC } \\
\begin{array}{llll}\text { a. } 14 \text { DAT } & \text { b. } 18 \text { DAT } & \text { c. } 20 \text { DAT } & \text { d. } 22 \text { DAT }\end{array}\end{array}$ \\
\hline 17 & 30 & What are the nutrient deficiency symptoms of $\mathrm{N}$ \\
\hline 18 & 31 & $\begin{array}{l}\text { What is the period of active tillering } \\
\begin{array}{llll}\text { a. } 35-40 & \text { b. } 50-55 & \text { c. } 55-60 & \text { d. } 70-75\end{array}\end{array}$ \\
\hline 19 & 33 & At what stage of the crop you apply $\mathrm{N}$ and $\mathrm{K}$ fertilizers \\
\hline 20 & 34 & Do you agree that the fully opened third leaf from the top as index leaf to compare LCC. (Yes/No) \\
\hline 21 & 37 & What is the deficiency symptoms of Zinc \\
\hline 22 & 39 & $\begin{array}{l}\text { Do you think that the appropriate time for application of pre-emergence herbicide is after the emergence of seedlings of } \\
\text { paddy _ (T/F) }\end{array}$ \\
\hline 23 & 40 & Do you know that, the herbicide is mixed with the sand before application__ (Yes/No) \\
\hline 24 & 43 & What are the Nutrient deficiency symptoms of K (Potassium deficiency) \\
\hline 25 & 44 & $\begin{array}{l}\text { Do you agree that, usage of rotary weeder not saves labour, not aerates soil and root zone and also not prolongs root } \\
\text { activity__ (T/F) }\end{array}$ \\
\hline 26 & 45 & Do you know that, irrigation should not be given after herbicide application and also water should not be drained out (Yes/No) \\
\hline 27 & 46 & At what leaf stage of the weeds, the Post-emergence herbicide is to be applied in the paddy field \\
\hline 28 & 49 & Do you think, puddling and leveling maximize the water requirement $(\mathrm{T} / \mathrm{F})$ \\
\hline 29 & 50 & Leaves fold longitudinally and larvae remains inside is a symptom of \\
\hline 30 & 52 & $\begin{array}{l}\text { Which pest can be controlled using Poison bait at } 1 \text { part zinc phosphide with } 49 \text { parts popped corn/rice/dry fish } \\
\text { a. Rat b. Cat c. Bat d. Earhead bug }\end{array}$ \\
\hline 31 & 53 & $\begin{array}{l}\text { What happens to paddy crop during booting and maturity stages when it is completely inundated } \\
\text { a. Root decay b. Leaf fall c. Stemfall d. Poor fruit set }\end{array}$ \\
\hline 32 & 55 & Do you feel that, keeping the field weed free, trimming the field bunds, provide effective drainage pest population \\
\hline 33 & 57 & Avoiding excess application of ' $\mathrm{N}$ ' fertilizer controls the pest population___ $(\mathrm{T} / \mathrm{F})$. \\
\hline 34 & 58 & Do you agree that, usage of rotary weeder prolongs root activity \\
\hline 35 & 60 & Circular patches of drying and lodging of matured plant is a symptom of $\mathrm{BPH} .(\mathrm{T} / \mathrm{F})$ \\
\hline
\end{tabular}

* Items selected for final inclusion

\section{Validity of the test items}

The validity of the test items was tested by the method of correlation coefficient (r) and content validity. The items belonged to 'very good' category (i.e., the items with point biserial correlation value of $0.40-0.70$ ) were considered to measure the knowledge of the unreached farmers on recommended crop production package of practices. Also the content validity of the knowledge test was derived from a long list of test items representing the whole universe on recommended crop production package of practices on paddy was collected by refereeing crop production guide of Tamil Nadu Agricultural University Agritech portal as discussed
Thus, the knowledge test developed, exactly measures the knowledge of unreached farmers on recommended crop production package of practices of paddy as it showed a greater degree of reliability and validity.

\section{RESULTS}

The table 2 represents the final knowledge items (i.e., thirty five (35)) selected for assessing the knowledge level of farmers on recommended crop production package of practices on paddy crop. The scale standardized may be directly used by a researcher for assessing knowledge level of farmers on recommended crop production package of 
practices. The items selected finally using standard procedures includes different aspects of crop production and different form of questions viz., choose the best answers, yes or no type questions, true or false and fill up the blanks.

\section{Acknowledgement}

With endless pleasure, I wish to express my indebtedness and deep sense of gratitude to my beloved Guide and esteemed Chairman of the advisory committee Dr. G. Samuel, Professor and Professors of the Department of Agricultural Extension, College of Agriculture, PJTSAU, Rajendranagar, Hyderabad, Telangana State, India for their guidance, untiring attention, sustained help and keen interest evinced.

\section{Reference}

Kerlinger, F.N. 1973. Foundations of behavioral research.Holt, Rinehart and Winston. New York.

McGahee, T.W. and Ball, J. 2009. How to read and really use an item analysis.Nurse Educator, 34: 166-171.

Penn, B.K. 2009. Test item development and analysis. Presented at Creighton University School of Nursing Faculty Retreat, Omaha, Nebraska, US.

Seemavarma.2015. Preliminary Item Statistics Using PointBiserial Correlation and P-values, Education data System, Morgan Hill, California.

Singh, A.K. 1986. Tests, Measurement and Research Methods in behavioural Sciences, Tata Mcgraw-Hill Publishing Company Ltd., New Delhi.

\section{How to cite this article:}

Sureshverma R et al (2017) ' Construction Of Knowledge Test To Measure The Paddy Growers knowledge On Recommended Crop Production Package Of Practices In Tamil Nadu State', International Journal of Current Advanced Research, 06(05), pp. 3867-3871.DOI: http://dx.doi.org/10.24327/ijcar.2017.3871.0384 